\title{
Insect Venom Immunotherapy: Analysis of the Safety and Tolerance of 3 Buildup Protocols Frequently Used in Spain
}

\author{
Gutiérrez Fernández D1, Moreno-Ancillo $\mathrm{A}^{2}$, Fernández Meléndez $\mathrm{S}^{3}$, \\ Domínguez-Noche $\mathrm{C}^{4}$, Gálvez Ruiz $\mathrm{P}^{5}$, Alfaya Arias $\mathrm{T}^{6}$, and the remaining \\ members of the SEAIC Committee on Allergy to Hymenoptera: Carballada \\ González FJ, Alonso Llamazares A, Marques Amat LL, Vega Castro A, Antolín \\ Amérigo D, Cruz Granados $S$, Ruiz León B, Sánchez Morillas L, Fernández \\ Sánchez J, Soriano Gomis V, Borja Segade JM, Dalmau Duch G, Guspi Bori R, \\ Miranda Páez A
}

'Servicio Neumología-Alergia, Hospital Universitario Puerta Mar, Cádiz, Spain

${ }^{2}$ Servicio de Alergología, Hospital Nuestra Señora del Prado, Talavera de la Reina, Spain

${ }^{3}$ Servicio de Alergología, Hospital Regional Carlos Haya, Málaga, Spain

${ }^{4}$ Servicio Alergología, Hospital Virgen Puerto, Plasencia, Spain

${ }^{5}$ Facultad de Educación, Universidad Internacional de La Rioja, Spain

${ }^{6}$ Servicio Alergología, Hospital General Universitario, Ciudad Real, Spain

J Investig Allergol Clin Immunol 2016; Vol. 26(6): 366-373

doi: 10.18176/jiaci.0073

\begin{abstract}
Introduction: Hymenoptera venom immunotherapy (VIT) is an effective treatment but not one devoid of risk, as both local and systemic adverse reactions may occur, especially in the initial phases. We compared the tolerance to 3 VIT buildup protocols and analyzed risk factors associated with adverse reactions during this phase.

Materials and Methods: We enrolled 165 patients divided into 3 groups based on the buildup protocol used (3, 4, and 9 weeks). The severity of systemic reactions was evaluated according to the World Allergy Organization model. Results were analyzed using exploratory descriptive statistics, and variables were compared using analysis of variance.

Results: Adverse reactions were recorded in 53 patients (32\%) (43 local and 10 systemic). Local reactions were immediate in 27 patients $(63 \%)$ and delayed in $16(37 \%)$. The severity of the local reaction was slight/moderate in 15 patients and severe in 13 . Systemic reactions were grade 1-2. No significant association was found between the treatment modality and the onset of local or systemic adverse reactions or the type of local reaction. We only found a statistically significant association between severity of the local reaction and female gender. As for the risk factors associated with systemic reactions during the buildup phase, we found no significant differences in values depending on the protocol used or the insect responsible.

Conclusions: The buildup protocols compared proved to be safe and did not differ significantly from one another. In the population studied, patients undergoing the 9-week schedule presented no systemic reactions. Therefore, this protocol can be considered the safest approach.

Key words: Allergy. Immunotherapy. Insect venom immunotherapy. Buildup protocols. Systemic reaction. Local reaction. Hymenoptera. Apis mellifera. Vespula species. Polistes species.
\end{abstract}

\section{Resumen}

Introducción: La inmunoterapia con veneno de himenópteros (ITV) es un tratamiento eficaz, pero no está desprovisto de riesgo ya que pueden ocurrir reacciones adversas locales o sistémicas, especialmente en las etapas iniciales del tratamiento. Comparamos la tolerancia de tres protocolos de inicio de ITV y analizamos los factores de riesgo asociados con las reacciones adversas que se produjeron en esta fase. 
Métodos: Se incluyeron 165 pacientes divididos en tres grupos según el protocolo de iniciación utilizado (3, 4 o 9 semanas). Evaluamos la gravedad de las reacciones sistémicas de acuerdo con el modelo de la Organización Mundial de Alergia. Analizamos los resultados mediante estadística descriptiva exploratoria y comparamos variables mediante el análisis de la varianza.

Resultados: Cincuenta y tres pacientes (32\%) experimentaron algún tipo de reacción adversa; 43 eran locales y 10 sistémicas. Las reacciones locales fueron inmediatas en 27 pacientes (63\%) y tardías en 16 (37\%). La gravedad de la reacción local fue leve o moderada en 15 pacientes y grave en 13. Las reacciones sistémicas fueron de grado 10 2. No encontramos asociación significativa entre la modalidad de tratamiento y la aparición de reacciones adversas locales o sistémicas o el tipo de reacción local. Solo encontramos una asociación estadísticamente significativa de la gravedad de la reacción local con el sexo femenino. En cuanto a los factores de riesgo asociados con las reacciones sistémicas en la fase de inicio, no se encontraron diferencias significativas en estos valores en función del protocolo utilizado o el insecto responsable.

Conclusiones: Los protocolos de inicio comparados demostraron ser seguros y no difirieron significativamente entre sí. En la población estudiada, el protocolo de 9-semanas no produjo reacciones sistémicas, por lo que se puede considerar el protocolo más seguro.

Palabras clave: Alergia. Inmunoterapia. Inmunoterapia con veneno de insectos. Protocolos de inicio. Reacción sistémica. Reacción local. Himenópteros. Apis mellifera. Vespula spp. Polistes spp.

\section{Introduction}

In insect venom-allergic patients, immunotherapy with the venom triggering the reaction is a very effective approach that confers protection against future stings in over $95 \%$ of cases. However, this treatment is not without risk, as local and systemic adverse reactions may occur, especially in the buildup phase. Consequently, treatment is administered periodically and in a hospital setting. This approach is very costly for both the patient and the health care system and can result in poor adherence. In a conventional venom immunotherapy buildup schedule, injections are administered once weekly for several weeks to reach the maintenance dose capable of providing protection against a new sting. Since immunotherapy must be administered in hospitals with the appropriate resources and experience, costs are high because of the need for frequent visits, travel time, and waiting time. Therefore, to reduce the number of hospital visits, clustered initial treatment modalities have been proposed and have proven as effective and safe as conventional protocols [1-6].

The Committee on Allergy to Hymenoptera of the SEAIC recently collected data on the 3 most frequently used protocols in Spanish hospitals (Tables 1 and 2). The protocols were administered depending on the facilities available and the experience of the prescribing allergologist. The 3 protocols were conventional treatment lasting 9 weeks and clustered treatments lasting 3 and 4 weeks.
The aim of the study was to assess and compare the tolerance and safety of the 3 protocols in the context of a prospective multicenter study involving 13 Spanish hospitals where immunotherapy with insect venom was administered following one of the protocols.

Table 1. Conventional Protocol

\begin{tabular}{llll}
\hline \multicolumn{4}{c}{ Initial 9-Week Protocol } \\
Week & $\begin{array}{l}\text { Concentration, } \\
\mu \mathrm{g} / \mathrm{mL}\end{array}$ & Dose, $\mathrm{mL}$ & Dose, $\mu \mathrm{g}$ \\
\hline 1 & 1 & 0.1 & 0.1 \\
2 & 10 & 0.1 & 1 \\
3 & 10 & 0.5 & 5 \\
4 & 100 & 0.1 & 10 \\
5 & 100 & 0.2 & 20 \\
6 & 100 & 0.4 & 40 \\
7 & 100 & 0.6 & 60 \\
8 & 100 & 0.8 & 80 \\
9 & 100 & 1 & 100
\end{tabular}

Maintenance treatment: once the maintenance dose is reached $(1 \mathrm{~mL}$ of the $100-\mu \mathrm{g} / \mathrm{mL}$ concentration), the interval between administrations is 4 weeks. This may be increased to 6-8 weeks at the allergist's discretion

Table 2. Cluster Schedules

\begin{tabular}{|c|c|c|c|c|c|c|c|}
\hline Day & Concentration, $\mu \mathrm{g} / \mathrm{mL}$ & Dose, $\mathrm{mL}$ & Dose, $\mu \mathrm{g}$ & Day & Concentration, $\mu \mathrm{g} / \mathrm{mL}$ & Dose, $\mathrm{mL}$ & Dose, $\mu \mathrm{g}$ \\
\hline \multirow[t]{2}{*}{1} & 10 & 0.5 & 5 & \multirow[t]{4}{*}{1} & 10 & 0.5 & 5 \\
\hline & 100 & 0.1 & 10 & & 100 & 0.1 & 10 \\
\hline \multirow[t]{2}{*}{8} & 100 & 0.2 & 20 & & 100 & 0.2 & 20 \\
\hline & 100 & 0.3 & 30 & & 100 & 0.2 & 20 \\
\hline \multirow[t]{2}{*}{15} & 100 & 0.5 & 50 & \multirow[t]{2}{*}{8} & 100 & 0.5 & 50 \\
\hline & 100 & 0.5 & 50 & & 100 & 0.5 & 50 \\
\hline 29 & 100 & 1 & 100 & 22 & 100 & 1 & 100 \\
\hline
\end{tabular}

Maintenance treatment: once the maintenance dose is reached $(1 \mathrm{~mL}$ of the $100-\mu \mathrm{g} / \mathrm{mL}$ concentration), the interval between administrations is 4 weeks. This may be increased to 6-8 weeks at the allergist's discretion. 


\section{Materials and Methods}

This observational, nonrandomized, prospective, and multicenter study was performed under conditions of normal clinical practice between June 2011 and June 2013. Purposive sampling was used to ensure a $99 \%$ confidence level $(Z=2.58)$, and the patients enrolled were insect venomallergic patients who had been scheduled for immunotherapy in the period specified. The patients were assigned to 1 of the 3 recommended protocols $(3,4$, and 9 weeks) based on the clinical practice of the participating center. Patients were included consecutively until a minimum of 55 patients for each protocol was achieved. Finally a total of 165 patients were included (121 men and 44 women; 55 patients in each of the recommended protocols).

We compared the protocols with various venom extracts, because adverse events can occur during immunotherapy, especially in the buildup phase, with venom from all insects. The data were collected from real-life clinical practice. Each participating group followed their habitual protocol.
The information collected for each patient was as follows: background data, the reactions experienced after the sting, the insect responsible, total serum IgE levels, levels of specific IgE against the different venoms, and serum tryptase levels. Patients were also asked if they were concurrently taking angiotensin-converting enzyme (ACE) inhibitors or angiotensin receptor blockers (ARBs) (Table 3).

The presence of local and/or systemic reactions to immunotherapy was recorded, as was the use of premedication. Local reactions were classified according to the criteria set out in Table 3. The severity of the systemic reactions was established using the World Allergy Organization classification (Table 4) [6]. The presence of local and systemic reactions and the severity of these reactions with each protocol were compared and expressed as the percentage of patients who experienced a reaction and as the percentage of injections that caused a reaction. Other risk factors for systemic reactions (eg, time elapsed since the last sting, venom responsible, and tryptase levels) were also analyzed.

Table 3. Data Collection Form

\begin{tabular}{|c|c|c|}
\hline Patient/Hospital code & & \\
\hline \multicolumn{3}{|l|}{ Age } \\
\hline Sex & [ ] MALE & [ ] FEMALE \\
\hline \multicolumn{3}{|l|}{ Clinical atopy and sensitizations } \\
\hline Relative of a beekeeper? & [ ] YES & {$[$ ] NO } \\
\hline \multicolumn{3}{|l|}{ Profession } \\
\hline Home setting & [ ] Rural & [ ] Urban (>10 000 inhabitants) \\
\hline \multicolumn{3}{|c|}{ Time since last sting until beginning of immunotherapy, mo } \\
\hline Insect responsible & $\begin{array}{l}{[\text { ] Bee }} \\
{[\text { ] Other }}\end{array}$ & $\begin{array}{l}\text { [ ] Polistes [ ] Vespula [ ] Bombus } \\
\text { [ ] Not known }\end{array}$ \\
\hline \multicolumn{3}{|l|}{ Baseline specific IgE, $\mathrm{kU} \mathrm{A}_{\mathrm{A}} / \mathrm{L}$} \\
\hline \multicolumn{3}{|l|}{ Extract used and composition } \\
\hline Initial schedule used & [ ] $9 \mathrm{wk}$ & [ ] $4 \mathrm{wk} \quad[$ ] $3 \mathrm{wk}$ \\
\hline Premedication & [ ] YES & [ ] NO \\
\hline \multicolumn{3}{|l|}{ Total IgE } \\
\hline \multicolumn{3}{|l|}{ Serum tryptase } \\
\hline \multicolumn{3}{|l|}{ REMA score } \\
\hline Taking angiotensin-converting enzyme inhibitors & [ ] YES & {$[$ ] NO } \\
\hline Taking angiotensin receptor blockers & [ ] YES & [ ] NO \\
\hline
\end{tabular}

Local Adverse Reactions

[ ] NO (with either medication) [ ] YES (complete as necessary)

\begin{tabular}{l|l|l|l}
\hline Date & Dose & Type (immediate, delayed) & Severity: mild, $<5 \mathrm{~cm} ;$ moderate, $5-10 \mathrm{~cm} ;$ severe, $>10 \mathrm{~cm}$. \\
\hline & & & \\
\hline
\end{tabular}

Systemic Adverse Reactions

[ ] NO (with either medication)

[ ] YES (complete as necessary)

\begin{tabular}{l|l|l|l}
\hline Date & Dose & Severity (grade 1, 2, 3, or 4) & Time to onset of first symptom, min
\end{tabular}

Abbreviations: REMA, Red Española de Mastocitosis (Spanish Network on Mastocytosis). 
We used commercially available lyophilized and aqueous extracts obtained from various pharmaceutical companies in Spain. The study was approved by the local ethics committees, and all patients provided their written informed consent.

Data were managed and the statistical analysis performed using IBM SPSS Statistics for Windows, Version 21.0 (IBM Corp), and exploratory descriptive techniques were applied to the different variables collected. The patients were divided into 3 groups depending on the protocol administered. The mean (SD), minimum and maximum, and 95\%CI were calculated. Associations between variables were analyzed using contingency tables. The chi-square test was used to compare nominal variables, and the Mann-Whitney test was used to compare scores from the patient groups. Analysis of variance was used for multiple comparisons.

\section{Results}

The mean age of the study participants was $45.96(17.56)$ years (range, 7-79 years). Men outnumbered women (73.3\%), and most patients were from rural areas $(64.2 \%)$. The 3-week (38\%) and 9 -week (45\%) protocols were the most frequently used for Apis venom, and the 4-week protocol was the most frequently used for Polistes venom (56\%). Premedication was administered in $27 \%$ and $13 \%$ of cases in the 3- and 9-week protocols and in $45 \%$ of cases in the 4 -week protocol (Table 5). The decision to use premedication depended on the clinical practice of each participating center. Local adverse reactions were recorded in $53 \%$ of patients who had taken premedication and in $15.3 \%$ of those who had not $(P<.01)$. Furthermore, systemic adverse reactions were recorded in $19.1 \%$ of patients who had taken premedication and in only $0.9 \%$ of those who had not $(P<.01)$.

Table 4. World Allergy Organization Subcutaneous Immunotherapy Systemic Reaction Grading System (Modified From [6])

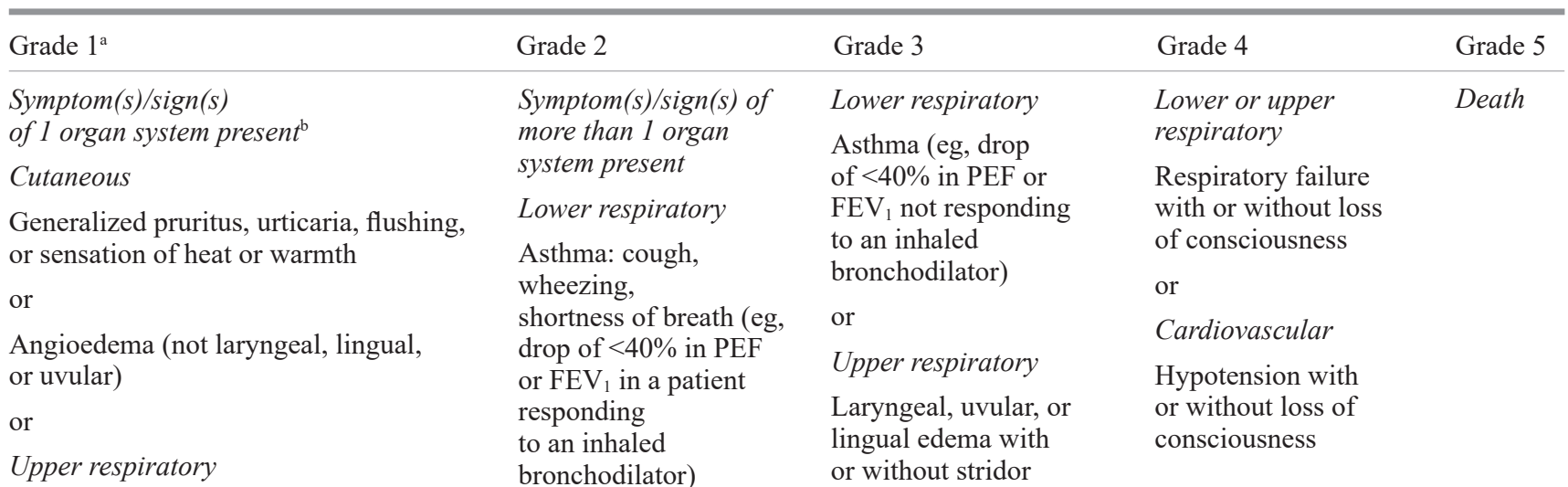

Rhinitis (eg, sneezing, rhinorrhea, nasal pruritus, and/or nasal congestion) or

Throat clearing (itchy throat)

or bronchodilator) or without stridor

or

\section{Gastrointestinal}

Abdominal cramps, vomiting, or diarrhea

Cough perceived to come from the upper airway, notthelung, larynx, or trachea

or

Other or

Uterine cramps

Conjunctival erythema, pruritus, or tearing

Other

Nausea, metallic taste, or headache

aEach Grade is based on the organ system involved and severity. Organ systems are defined as cutaneous, conjunctival, upper respiratory, lower respiratory, gastrointestinal, cardiovascular, and other. A reaction from a single organ system such as cutaneous, conjunctival, or upper respiratory, but not asthma, gastrointestinal, or cardiovascular is classified as Grade 1. Symptom(s)/sign(s) from >1 organ system or asthma, gastrointestinal, or cardiovascular are classified as Grades 2 or 3. Respiratory failure or hypotension, with or without loss of consciousness, is classified as Grade 4. Death is classified as Grade 5 . The grade is based on the physician's clinical judgment.

bPatients may also have a feeling of impending doom, especially in grades 2, 3, or 4. Children with anaphylaxis seldom convey a sense of impending doom, and changes in their behavior may be a sign of anaphylaxis, eg, becoming very quiet or irritable and cranky. Scoring includes a suffix that denotes if and when epinephrine is administered in relationship to symptom(s)/sign(s) of the systemic reaction: $a, \leq 5$ minutes; $b,>5$ minutes to $\leq 10$ minutes; $c,>10$ to $\leq 20$ minutes; $d,>20$ minutes; $z$, epinephrine not administered. The final grade of the reaction will not be determined until the event is over, regardless of the medication administered. The final report should include the first symptom(s)/sign(s) and the time of onset after the subcutaneous allergen immunotherapy injection and a suffix reflecting if and when epinephrine was or was not administered, eg, Grade 2a; rhinitis: 10 minutes. 
Table 5. Patient Characteristics by Protocol

\begin{tabular}{|c|c|c|c|}
\hline Parameter & 3-Week & 4-Week & 9-Week \\
\hline \multicolumn{4}{|l|}{ Age } \\
\hline Mean (SD) & $49.64(16.80)$ & 39.55 (18.59) & $48.71(15.63)$ \\
\hline Range & $72(7-79)$ & $70(7-77)$ & $64(14-78)$ \\
\hline \multicolumn{4}{|l|}{ Gender } \\
\hline Female & $15(27 \%)$ & $17(31 \%)$ & $12(33 \%)$ \\
\hline Male & $40(73 \%)$ & $38(69 \%)$ & $43(78 \%)$ \\
\hline \multicolumn{4}{|l|}{ Home setting } \\
\hline Rural & $29(53 \%)$ & $35(64 \%)$ & $42(76 \%)$ \\
\hline Urban & $26(47 \%)$ & $20(36 \%)$ & $13(24 \%)$ \\
\hline \multicolumn{4}{|l|}{ Atopy } \\
\hline Yes & $37(67 \%)$ & $31(56 \%)$ & $46(84 \%)$ \\
\hline No & $18(33 \%)$ & $24(44 \%)$ & $9(16 \%)$ \\
\hline \multicolumn{4}{|l|}{ Premedication } \\
\hline Yes & $15(27 \%)$ & $25(45 \%)$ & $7(13 \%)$ \\
\hline No & $40(73 \%)$ & $30(55 \%)$ & $48(87 \%)$ \\
\hline \multicolumn{4}{|l|}{ Species responsible } \\
\hline Polistes & $20(36 \%)$ & $31(56 \%)$ & $14(26 \%)$ \\
\hline Apis & $21(38 \%)$ & $15(27 \%)$ & $25(45 \%)$ \\
\hline Vespula & $14(26 \%)$ & $8(15 \%)$ & $15(27 \%)$ \\
\hline Bombus & $0(0 \%)$ & $1(2 \%)$ & $1(2 \%)$ \\
\hline \multicolumn{4}{|l|}{ Local reaction } \\
\hline Yes & $16(29 \%)$ & $19(34 \%)$ & $8(14 \%)$ \\
\hline No & $39(71 \%)$ & $36(66 \%)$ & $47(86 \%)$ \\
\hline \multicolumn{4}{|l|}{ Systemic reaction } \\
\hline Yes & $5(9 \%)$ & $5(9 \%)$ & $0(0 \%)$ \\
\hline No & $50(91 \%)$ & $50(91 \%)$ & $55(100 \%)$ \\
\hline \multicolumn{4}{|l|}{ Serum tryptase } \\
\hline Mean (SD) & $4.94(2.73)$ & $5.02(4.09)$ & $4.48(2.35)$ \\
\hline Patients analyzed & $55 / 55$ & $38 / 55$ & $10 / 55$ \\
\hline
\end{tabular}

No significant differences were found between the protocols for baseline serum tryptase levels $(P=.89)$, mean initial specific $\operatorname{IgE}$ values $(P=.53)$, or initial total $\operatorname{IgE}$ values $(P=.54)$. No statistically significant association was detected between the score of the Spanish Network on Mastocytosis (Red Española de Mastocitosis [REMA]) and adverse reactions.

Among the 165 patients, Polistes was the species responsible in 65 patients (40\%), Apis in 61 patients $(37 \%)$, Vespula in 37 patients (22\%), and Bombus in 2 patients (1\%). A total of 1265 injections were administered; of these, 385 corresponded to the 3- and 4-week protocols (30.4\% each) and $495(39.2 \%)$ to the 9 -week protocol.

Ten systemic reactions were recorded $(6 \%$ of all patients, $0.8 \%$ of all injections). Five occurred in the 3 -week protocol ( $9 \%$ of the patients in this group) and 5 in the 4 -week protocol ( $9 \%$ of the patients). A total of 43 local reactions were recorded (26\% of all the patients and $3.4 \%$ of the total number of injections), and most of them (81.4\%) occurred in the 3 - and 4-week protocols (Table 5).

Based on the classification system used [6], the severity of the systemic reactions was grade 1 in 7 patients and grade 2 in 3 patients. There were no cases of grade 3 or 4 reactions.

Local reactions were immediate in 27 patients $(63 \%)$ and delayed in 16 patients ( $37 \%$ ); the severity of the reaction was mild in 13 patients $(8 \%)$, moderate in $15(9 \%)$, and severe in $14(8 \%)$.
No concurrent local reaction was detected in half of the patients experiencing a systemic reaction ( 5 patients). The local reactions in the other 5 patients who experienced a systemic reaction were immediate in 4 cases and delayed in the rest. The severity of these local reactions was mild in 1 patient, moderate in 2 and severe in the other 2.

As for the buildup protocol applied, we found no significant association with the occurrence of local adverse reactions $(P=.47)$ or systemic adverse reactions $(P=.70)$ or with the severity of the systemic reaction $(P=.54)$ in the 3 - and 4 -week protocols. In contrast, significant differences were detected in the severity of the local reaction depending on the initial treatment, with a higher percentage of mild reactions for the 9-week protocol (Table 6); however, this result was influenced by the lower number of local adverse reactions in the 9 -week protocol, while the 3-week and 4-week protocols had at least double the number of local adverse reactions.

Bearing in mind the association between initial treatment and reactions, an analysis stratified by gender revealed that the severity of local reactions was significant depending on the initial treatment used in the case of women $\left(\chi^{2}[6]=20.687, P=.002\right)$ but not for men $\left(\chi^{2}[6]=7.234, P=.30\right)$. Women receiving the 3 -week protocol experienced moderate reactions in $31 \%$ of cases.

Nine patients $(7.5 \%)$ were found to be concurrently taking ARBs and 8 patients $(8.3 \%)$ were taking ACE inhibitors, 
Table 6. Buildup Protocols and Reactions

\begin{tabular}{|c|c|c|c|c|c|c|}
\hline & \multicolumn{6}{|c|}{ Initial Schedule } \\
\hline & & 3-Week & 4-Week & 9-Week & $\chi^{2}$ & $P$ Value \\
\hline \multirow[t]{2}{*}{ Local adverse reaction } & No & $39(32 \%)$ & $36(30 \%)$ & $47(38 \%)$ & & \\
\hline & Yes & $16(37 \%)$ & $19(44 \%)$ & $8(19 \%)$ & $6.102(2)$ & .47 \\
\hline \multirow[t]{3}{*}{ Severity of local reaction } & Slight & $2(14 \%)$ & $7(50 \%)$ & $5(36 \%)$ & & \\
\hline & Moderate & $7(47 \%)$ & $7(47 \%)$ & $1(6 \%)$ & $12.380(6)$ & .05 \\
\hline & Severe & $7(50 \%)$ & $5(36 \%)$ & $2(14 \%)$ & & \\
\hline \multirow[t]{2}{*}{ Systemic adverse reaction } & No & $50(32 \%)$ & $50(32 \%)$ & $55(36 \%)$ & $5.323(2)$ & .70 \\
\hline & Yes & $5(50 \%)$ & $5(50 \%)$ & $0(0 \%)$ & & \\
\hline \multirow[t]{3}{*}{ Type of reaction } & No & $3(60 \%)$ & $2(40 \%)$ & $0(0 \%)$ & & \\
\hline & Immediate & $2(50 \%)$ & $2(50 \%)$ & $0(0 \%)$ & $1.200(2)$ & .54 \\
\hline & Delayed & $0(0 \%)$ & $1(100 \%)$ & $0(0 \%)$ & & \\
\hline \multirow[t]{4}{*}{ Severity of systemic reaction } & Grade 1 & $3(43 \%)$ & $4(57 \%)$ & $0(0 \%)$ & & \\
\hline & Grade 2 & $2(67 \%)$ & $1(33 \%)$ & $0(0 \%)$ & $0.476(1)$ & .49 \\
\hline & Grade 3 & $0(0 \%)$ & $0(0 \%)$ & $0(0 \%)$ & & \\
\hline & Grade 4 & $0(0 \%)$ & $0(0 \%)$ & $0(0 \%)$ & & \\
\hline
\end{tabular}

Table 7. Insect Responsible for Systemic Reactions by Buildup Protocol

\begin{tabular}{llccc}
\hline $\begin{array}{l}\text { Initial } \\
\text { Schedule }\end{array}$ & $\begin{array}{l}\text { Systemic } \\
\text { Reactions }\end{array}$ & \multicolumn{4}{c}{ Species Responsible } \\
\hline & Totals & Apis & Polistes & Vespula \\
\hline 3-Week & 5 & $4(80 \%)$ & $1(20 \%)$ & $0(0 \%)$ \\
4-Week & 5 & $2(40 \%)$ & $2(40 \%)$ & $1(20 \%)$ \\
9-Week & 0 & $0(0 \%)$ & $0(30 \%)$ & $0(10 \%)$ \\
Total & 10 & $6(60 \%)$ & $3(30 \%)$ & $1(10 \%)$ \\
\hline
\end{tabular}

although no significant association was found with the occurrence of systemic reactions in patients taking either ARBs $(P=.34)$ or ACE inhibitors $(P=.07)$.

As for the time elapsed since the last sting, 73.9\% of patients began immunotherapy during the following 10 months. No significant association was found between serum tryptase levels and the occurrence of systemic reactions $(P=.68)$.

Of note, 8 of the patients who received immunotherapy with Apis extract were beekeepers. In 41 cases, the patients were relatives of a beekeeper: 36 received Apis extract, 2 received Polistes extract, and 3 received Vespula extract.

In the case of systemic reactions, the venom involved was principally from the species Apis (6 patients; 60\%) and Polistes (3 patients; 30\%), with Vespula being much less frequently involved (1 patient; 10\%). The most common range of systemic reactions was found in the 10 - and $50-\mu \mathrm{g}$ concentrations in the buildup protocol. When this issue was analyzed with reference to the protocol used, the species most frequently responsible in the group of patients with systemic reactions receiving the 3-week protocol was Apis (4 patients) followed by Polistes (1 patient). For the initial 4-week treatment, both Apis and Polistes were involved in 2 cases and Vespula in only 1 case. Interestingly, no cases were detected in the 9-week protocol (Table 7). The occurrence of systemic reactions showed no significant association with the insect responsible $(P=.453)$, as was the case with gender for men $(P=.126)$ and women
$(P=.891)$. Similarly, no significant differences were found in mean initial specific $\operatorname{IgE}$ values $(P=.135)$ depending on the insect responsible.

\section{Discussion}

The 3 buildup protocols we examined proved to be safe and well-tolerated in the patients studied, with only $6 \%$ experiencing a systemic reaction, ie, $0.8 \%$ of all injections given. Few prospective studies have compared buildup protocols of venom immunotherapy [7-10], and no studies to date have compared a conventional 9-week protocol with clustered 3- and 4-week protocols. Buildup protocols are difficult to compare given the many differences between them (eg, patients selected, protocols used, extracts, and recording of adverse reactions), thus no doubt explaining why the prevalence of systemic reactions reported in the literature is so variable, ranging from $2 \%$ [11] to $21 \%$ [12]. The true figure most probably lies between 5\% and 15\% [13]. In a recent prospective multicenter study by the EAACI, the frequency of systemic reactions was $8.4 \%$ across the different protocols used [14]. The type of buildup protocol that should be applied to reach the maintenance dose remains a matter of debate. Standard protocols (lasting 8-15 weeks), rush protocols (4-7 days), and ultrarush protocols (1-2 days) can all be used. Ultrarush protocols have been shown to be safe $[9,12,15$ 17]; however, other prospective studies have shown a rapid increase in dose to be an independent risk factor for adverse systemic reactions $[13,18]$. In the case of ultrarush protocols, this risk is increased 1.8-fold, although the protocols are costeffective $[19,20]$. We chose 3 protocols that had already been successfully tested by different groups in Spain $[8,21]$ and are the approach used in most allergy departments in Spain.

Most of the patients in our study were male (2.75:1) - a finding that is in line with most published studies $[11,13,14]$ and lived in a rural setting. The frequency of atopic patients $(31 \%)$ was also consistent with that of previous reports and is no higher than in the general population [13]. 
The primary objective of this study was to compare tolerance to 3 buildup protocols of immunotherapy with insect venom. Therefore, the data collection form included not only adverse reactions, but also all the risk factors that were associated with systemic reactions during the initial phases of treatment. Of note, we determined baseline tryptase values [14] in $62 \%$ of patients. The mean value was $4.93 \mu \mathrm{g} / \mathrm{L}$, and there were no significant differences in this parameter according to the protocol used $(P=.89)$ or the species responsible $(P=.29)$. The mean tryptase value was $4.95 \mu \mathrm{g} / \mathrm{L}$ in the 3 -week protocol $(\mathrm{n}=55$ patients), $5.02 \mu \mathrm{g} / \mathrm{L}$ in the 4 -week protocol $(\mathrm{n}=38$ patients), and $4.48 \mu \mathrm{g} / \mathrm{L}$ in the 9 -week protocol ( $\mathrm{n}=10$ patients). These data contrast with those of other prospective studies, which reported tryptase levels of $>11.4 \mu \mathrm{g} / \mathrm{L}$ in $10 \%$ of patients and $>20 \mu \mathrm{g} / \mathrm{L}$ in $2.6 \%$ [14]; in our series, the maximum tryptase value observed was $10 \mu \mathrm{g} / \mathrm{L}$. However, since tryptase level was measured in only $62 \%$ of the patients included, the value might have differed if it had been measured in all patients.

As for other risk factors associated with systemic reactions in the initial phases of treatment (antihypertensive medication, patient age, and time between the sting and the beginning of immunotherapy), we found no significant associations with any local or systemic reaction.

In the present study, 43 patients $(26 \%)$ experienced local reactions, but only 13 reactions $(8 \%)$ were considered to be severe $(>10 \mathrm{~cm})$. No significant association was found between onset of the local reactions and the protocol used $(P=.47)$, although the severity of the reaction was significant for buildup protocols $(P<.05)$, with the reactions being significantly less severe in the 9-week protocol. Furthermore, when data were stratified by gender, the association was highly significant in women $(P=.002)$, but not in men $(P=.30)$. Although this finding has not been reported elsewhere, some studies have shown female sex to be a risk factor-albeit a less important one-for adverse reactions in the initial stages of immunotherapy with insect venom [13]. Systemic reactions are generally more severe in men [21]. Furthermore, we found no significant association between local reactions and the species responsible $(P=.082)$.

Ten patients in our study experienced systemic reactions, ie, $6 \%$ of the total number of patients and $0.8 \%$ of the total number of injections. All the systemic reactions were mild, and none required adrenaline. This prevalence of systemic reactions is on the lower limit of the published mean [13] and similar to that of immunotherapy with inhalant allergens. The 3-week protocol was used in 5 of the 10 patients, and the 4 -week protocol in the other 5 . None of the patients included in the 9 -week protocol experienced systemic reactions. Analysis of the 10 patients with systemic reactions failed to identify associated risk factors (age, gender, time between last sting and beginning of immunotherapy, and atopy). However, in all patients, the time between the last sting and the beginning of immunotherapy was over 2 months, which is considered the cutoff for considering this a risk factor [14].

No significant differences were found in the levels of total or specific IgE or tryptase levels in the group of patients with systemic reactions. As a result, we did not identify any of the significant risk factors proposed by other authors [14,16,22].

No significant differences were found for the species responsible $(P=.45)$, although 6 of the 10 patients with systemic reactions were receiving immunotherapy with bee venom.
Many studies have shown that bee venom is an independent risk factor for adverse reactions during immunotherapy [12,14,18,23-25], whereas others showed no significant difference in the number of systemic reactions when comparing patients receiving wasp or bee venom extract [26]. However, our findings could well be the result of the small sample size.

Hymenoptera venom allergy has been shown to be closely associated with mastocytosis, and insect venom allergy is highly prevalent in patients with any form of mastocytosis [27,28]. Although a REMA score $\geq 2$ can predict the presence of mastocytosis [24], it was not related to the presence of adverse reactions during hymenoptera venom immunotherapy in the present study.

Premedication seemed to be unable to prevent adverse reactions; paradoxically, premedication was associated with more adverse reactions, probably because it was more frequently used in shorter protocols.

In conclusion, the 3 buildup protocols compared in this study were safe, with no significant differences between them. However, the absence of systemic reactions in the 9-week protocol is noteworthy.

\section{Funding}

The authors declare that no funding was received for the present study.

\section{Conflicts of Interest}

The authors declare that they have no conflicts of interest.

\section{References}

1. Antolín-Amérigo D, Moreno Aguilar C, Vega A, Alvarez-Mon M. Venom immunotherapy: An updated review. Curr Allergy Asthma Rep. 2014;14(7):1-12.

2. Sánchez-Machín I, Moreno C, González R, Iglesias-Souto J, Pérez E, Matheu V. Safety of a 2-Visit Cluster Schedule of Venom Immunotherapy in Outpatients at Risk of Lifethreatening Anaphylaxis. J Investig Allergol Clin Immunol. 2010; Vol. 20(1):89-92.

3. Carballada F, Boquete $M$, Nuñez R, Lombardero $M$, De la Torre F. Follow-up of Venom Immunotherapy (VIT) Based on Conventional Techniques and Monitoring of Immunoglobulin E to Individual Venom Allergens. J Invest Allergol Clin Immunol. 2010;20(6):506-13.

4. Carballada González FJ, Crehuet Almirall M, Manjón Herrero A, De la Torre F, Boquete París M. Hymenoptera venom allergy: characteristics, tolerance and efficacy of immunotherapy in the pediatric population. Allergol et Immunopathol. 2009;37(3):111-5.

5. Carballada F, Martin S, Boquete M. High efficacy and absence of severe systemic reactions after Venom Immunotherapy. J Invest Allergol Clin Immunol. 2003;13(1):43-9.

6. Cox L, Larenas-Linnemann D, Lockey RF, Passalacqua G. Speaking the same language: The world allergy organization subcutaneous immunotherapy systemic grading system. J Allergy Clin Immunol. 2010;125:569-74.

7. Wyss M, Scheitlin T, Stadler BM, Wüthrich B. Immunotherapy with aluminum hydroxide adsorbed insect venom extracts (Alutard SQ): immunologic and clinical results of a prospective study over 3 years. Allergy. 1993;48(2):81-6. 
8. Alessandrini AE, Berra D, Rizzini FL, Mauro M, Melchiorre A, Rossi F, Spezia D, Stanizzi R, Ricciardi L, Burastero SE. Flexible approaches in the design of subcutaneous immunotherapy protocols for hymenoptera venom allergy. Ann Allergy Asthma Immunol. 2006;97(1):92-7.

9. Patella V, Florio G, Giuliano A, Oricchio C, Spadaro G, Marone G, Genovese A. Hymenoptera venom immunotherapy: tolerance and efficacy of an ultrarush protocol versus a rush and slow conventional protocol. J Allergy. 2012;2012:191192.

10. Bilò MB, Cinti B, Brianzoni MF, Braschi MC, Bonifazi $M$, Antonicelli L. Honey bee venom immunotherapy: a comparative study using purified and nonpurified aqueous extracts in patients with normal basal serum tryptase concentrations. J Allergy. 2012;2012:869243.

11. Fernández-Meléndez S, Miranda A, Martín-Casáñez E. Alergia a veneno de himenópteros. En: Manual de Alergología; Miranda $A$, Fernández-Meléndez $S$, Delgado J, Barceló $M$, Anguita JL, Moya MC y Conde A, eds. ISBN: 978-84-6909549-2, Madrid, 2007; pp. 424-39.

12. Brehler R, Wolf H, Kütting B, Schnitker J, Luger T. Safety of a two-day ultrarush insect venom immunotherapy protocol in comparison with protocols of longer duration and involving a large number of injections. J Allergy Clin Immunol. 2000;105(6):1231-5

13. Golden DBK. Insect allergy. In: Middleton's Allergy: Principles \& Practice, seventh edition. Adkinson Jr NF, Brochner BS, Busse WW, Holgate ST, Lemanske Jr RF and Simons FER eds. ISBN: 978-0-323-05659-5. Elsevier Inc, Philadelphia, 2009; pp 1005-17.

14. Ruëff F, Przybilla B, Bilò MB, Müller U, Scheipl F, Aberer W, Birnbaum J, Bodzenta-Lukaszyk A, Bonifazi F, Bucher C, Campi P, Darsow U, Egger C, Haeberli G, Hawranek T, Kucharewicz I, Küchenhoff H, Lang R, Quercia O, Reider N, Severino M, Sticherling M, Sturm GJ, Wüthrich B; European Academy of Allergy and Clinical Immunology Interest Group. Predictors of side effects during the buildup phase of venom immunotherapy for hymenoptera venom allergy: the importance of baseline serum tryptase. European Academy of Allergy and Clinical Immunology Interest Group of Insect Venom Hypersensitivity. J Allergy Clin Immunol. 2010;126:105-11.

15. Ruëff $F$, Przybilla B. Ultrarush immunotherapy in patients with hymenoptera venom allergy. J Allergy Clin Immunol. 2001;107(5):928-9.

16. Birnbaum J, Ramadour M, Magnan A, Vervloet D. Hymenoptera ultra-rush venom immunotherapy (210 min): a safety study and risk factors. Clin Exp Allergy. 2003;33(1):58-64.

17. Pasaoglu G, Sin BA, Misirligil Z. Rush hymenoptera venom immunotherapy is efficacious and safe. I Invest Allergol Clin Immunol. 2006;16(4):232-8.

18. Mosbech $H$, Müller U. Side-effects of insect venom immunotherapy: results from an EAACl multicenter study. European Academy of Allergology and Clinical Immunology. Allergy. 2000;55:1005-10.

19. Ruëff F, Bilò MB, Cichocka-Jarosz E, Müller U, Oude Elberink H, Sturm G. Immunotherapy for hymenoptera venom allergy: too expensive for European healthcare? Allergy. 2013;68:407-8.

20. Hockenhull J, Elremeli M, Cherry MG, Mahon J, Lai M, Darroch J, Oyee J, Boland A, Dickson R, Dundar Y, Boyle R. A systematic review of the clinical effectiveness and cost-effectiveness of Pharmalgen ${ }^{\circledR}$ for the treatment of bee and wasp venom allergy. Health Technol Assess. 2012;16(12):1-110.

21. Moreno C, Guerra F. Inmunoterapia con veneno de himenópteros: seguridad de una pauta agrupada. Alergol Inmunol Clin. 1999; 14:315-21.

22. Ruëff $F$, Przybilla B, Bilò MB, Müller U, Scheipl F, Aberer W, Birnbaum J, Bodzenta-Lukaszyk A, Bonifazi F, Bucher C, Campi P, Darsow U, Egger C, Haeberli G, Hawranek T, Körner M, Kucharewicz I, Küchenhoff $H$, Lang R, Quercia O, Reider $\mathrm{N}$, Severino M, Sticherling M, Sturm GJ, Wüthrich B. Predictors of severe anaphylactic reactions in patients with hymenoptera venom allergy: importance of baseline serum tryptase -a study of the European Academy of Allergology and Clinical Immunology Interest Group on Insect Venom Hypersensitivity. J Allergy Clin Immunol. 2009;124:1047-54.

23. Lockey RF, Turkeltaub PC, Olive ES, Hubbard JM, Baird-Warren IA, Bukantz SC. The hymenoptera venom study III: safety of venom immunotherapy. J Allergy Clin Immunol. 1990;86:77580.

24. Müller U, Helbling A, Berchtold E. Immunotherapy with honeybee venom and yellow jacket venom is different regarding efficacy and safety. I Allergy Clin Immunol. 1992;89:529-35.

25. Pasaoglu G, Sin BA, Misirligil Z. Rush Hymenoptera Venom Immunotherapy Is Efficacious and Safe. J Investig Allergol Clin Immunol. 2006;16(4):232-238.

26. Roll A, Hofbauer G, Ballmer-Weber BK, Schmid-Grendelmeier P. Safety of specific immunotherapy using a four-hour ultrarush induction scheme in bee and wasp allergy. J Investig Allergol Clin Immunol. 2006;16(2):79-85.

27. Alvarez-Twose I, González de Olano D, Sánchez-Munoz L, Matito A, Esteban López MI, Vega A, Mateo MB, Alonso Díaz de Durana MD, de la Hoz B, Del Pozo Gil MD, Caballero T, Rosado A, Sánchez Matas I, Teodosio C, Jara-Acevedo $M$, Mollejo M, García-Montero A, Orfao A, Escribano L. Clinical, biological, and molecular characteristics of clonal mast cell disorders presenting with systemic mast cell activation symptoms. J Allergy Clin Immunol. 2010;125:1269-78.

28. Bonadonna P, Lombardo C, Zanotti R. Mastocytosis and Allergic Diseases. J Investig Allergol Clin Immunol. 2014;24(5):28897.

\section{Manuscript received October 12, 2015; accepted for publication April 19, 2016.}

\section{| Álvaro Moreno-Ancillo}

\author{
Servicio de Alergia \\ Hospital Ntra. Sra. Del Prado \\ Ctra. Madrid, km 114 \\ 45600 Talavera de la Reina (Toledo) \\ Spain \\ E-mail: a.morenoancillo@gmail.com
}

